\title{
Preparation and properties of native oxide film anodically grown on $\mathrm{Hg}_{0.8} \mathrm{Cd}_{0.2} \mathrm{Te}$
}

\author{
F R CHAVDA, G TIWARI and S C GUPTA \\ Solid State Physics Laboratory, Luck now Road. Delhi 110007 , Inda \\ MS received 1 February 1985; revised 5 February 1987
}

\begin{abstract}
tbstract. The process for forming the anodic oxide on $\mathrm{Hg}_{0}{ }_{8} \mathrm{Cd}_{0.2} \mathrm{Te}$ using a constant voltage d.c. source is studied. The electrolyte is composed of $0.1 \mathrm{~N} \mathrm{KOH}, 90 \%$ ethylene glycol and $10^{\circ}$ "water. Good, uniform. transparent and reproducible films are obtaincd when the $\mathrm{pH}$ of the solution is adjusted between 7 and 8 by using oxalic acid. The anodic oxide film shows an anti-reflection effect. $\mathrm{HCl}$ and $\mathrm{NH}_{4} \mathrm{OH}$ etch the oxide well and give a smooth polished surface of $\mathrm{Hg}_{0.8} \mathrm{Cd}_{0.2} \mathrm{Te}$.
\end{abstract}

Keywords. Anodic oxide: mercury cadmium telluride; pH value; native oxide; II-VI compounds.

\section{Introduction}

The pseudo-binary alloy $\mathrm{Hg}_{0 \cdot 8} \mathrm{Cd}_{0 \cdot 2} \mathrm{Te}$ is one of the most important semiconducting material for infrared applications. Photoconductive detectors, photodiodes, metalinsulator-semiconductors (MIS) diodes and charge coupled devices (CCDs) have been made using this material for the $8-14 \mu \mathrm{m}$ atmospheric window. The performance of these opto-electronic devices is closely related to the surface properties. It is limited by the surface leakage current as well as the electrical and the chemical stability of $\mathrm{Hg}_{0.8} \mathrm{Cd}_{0.2} \mathrm{Te}$. It is, therefore, necessary to passivate the surface of this material. Native oxide film anodically grown on $\mathrm{Hg}_{0.8} \mathrm{Cd}_{0.2} \mathrm{Te}$ has been used for surface passivation and preparation of MIS structure by various workers (Willardson and Beer 1981; Catagnus and Baker 1979; Dornhaus and Nimtz 1983). However, the chemical and optical properties of the film are not well reported in the literature. In this paper we describe the procedure for forming the anodic oxide film on $\mathrm{Hg}_{0.8} \mathrm{Cd}_{0 \cdot 2} \mathrm{Te}$ under constant voltage source. The chemical behaviour of the film to various organic and inorganic solvents and the antireflection effect of the film are also examined and discussed.

\section{Anodization procedure}

The $\mathrm{Hg}_{0.8} \mathrm{Cd}_{0.2}$ Te wafers used were both of $n$ and $p$-types with carrier concentration in the range $10^{15}-10^{17} \mathrm{~cm}^{-3}$ and with a random orientation. These crystals were obtained from New England Research Centre, USA. The surface of the wafers was prepared by first lapping with $3-5 \mu \mathrm{m} \mathrm{Al}{ }_{2} \mathrm{O}_{3}$ powder and then with $0.5 \mu \mathrm{m}$ powder. The lapped surface was then etched by a standard procedure for MCT using $2 \%$ $\mathrm{Br}_{2}+$ methanol solution prior to anodization to remove the damaged surface.

The set-up used for anodic oxidation is shown in figure 1. A graphite rod is used as the cathode. The electrolyte is a mixture of $0.1 \mathrm{~N} \mathrm{KOH}+90 \%$ ethylene glycol and $10 \% \mathrm{H}_{2} \mathrm{O}$. The anodic oxidation is carried out under normal light condition at room 


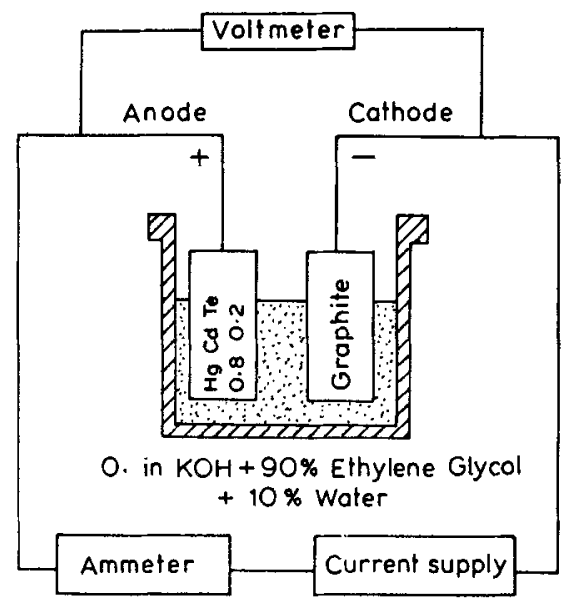

Figure 1. Systematic arrangement for anodizing $\mathrm{Hg}_{0 \cdot 8} \mathrm{Cd}_{0 \cdot 2} \mathrm{Te}$.

temperature using a constant voltage d.c. source. The cell voltage and the current are measured with time. The $\mathrm{pH}$ value of the prepared solution is found to be 12 and is alkaline in nature. The film grown in this solution at a current density $1 \mathrm{~mA} / \mathrm{cm}^{2}$ showed matte appearance. To improve the quality of the film, the parameters-the $\mathrm{pH}$ of the solution and the current density are varied and the effects are investigated. The $\mathrm{pH}$ value of the solution is varied from 5 to 11 by adding oxalic acid. The initial current density is varied from $0.2 \mathrm{~mA} / \mathrm{cm}^{2}$ to $2 \mathrm{~mA} / \mathrm{cm}^{2}$. During the growth it is observed that good, uniform shining and reproducible films are obtained when the $\mathrm{pH}$ is in the range 7-8 and current density $0.5-1 \mathrm{~mA} / \mathrm{cm}^{2}$. For further experiments the $\mathrm{pH}$ was kept equal to 8 and initial current density to $1 \mathrm{~mA} / \mathrm{cm}^{2}$. After anodization the samples are rinsed in deionized water for a few seconds and then dried in pure nitrogen gas flow. Figure 2 shows a typical example of the behaviour of the current and the voltage as a function of time during the anodization. The voltage increases linearly with time and saturates to the previously set value. The current decreases rapidly and then becomes a small constant value depending on the voltage. The reason for this small constant residual current is not established.

\section{Film properties}

The oxide film grown at the optimum value of $\mathrm{pH} 8$ and initial current density $1 \mathrm{~mA} / \mathrm{cm}^{2}$ are shining and transparent for all cell voltages upto $25 \mathrm{~V}$. The thickness of the oxide films as a function of cell voltage is determined by optical interferometry using the standard formula. A relation between the cell voltage and the thickness of the film is shown in figure 3 along with the colour of the film obtained at these cell voltages. The colour chart is similar to that obtained for anodic oxide of $\mathrm{Pb}_{0.94} \mathrm{Sn}_{0.06} \mathrm{Se}$ (Gupta and Richter 1983) and $\mathrm{SiO}_{2}$ (Ghandhi 1985). The thickness of the oxide film is also calculated theoretically by using the colour chart of $\mathrm{SiO}_{2}$ and the following relation

$$
n_{1} t_{1}=n_{2} t_{2}
$$

where $n_{1}$ and $n_{2}$ are the indices of refraction for $\mathrm{SiO}_{2}$ and oxide of MCT respectively 


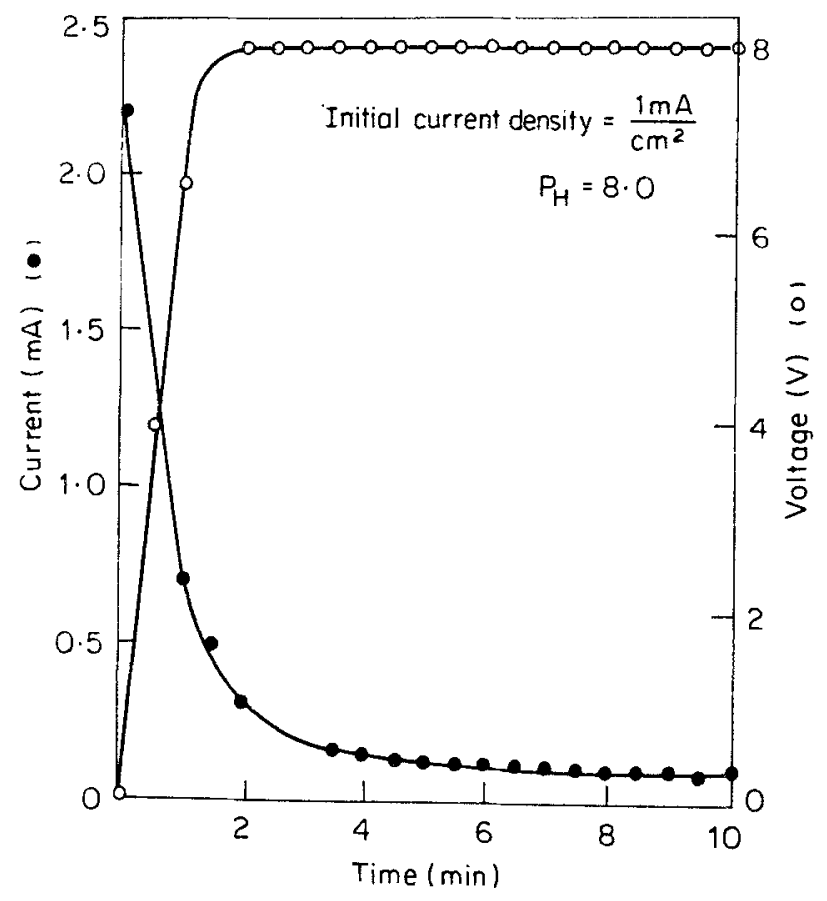

Figure 2. Time dependence of voltage and current during anodization under constant voltage d.c. source.

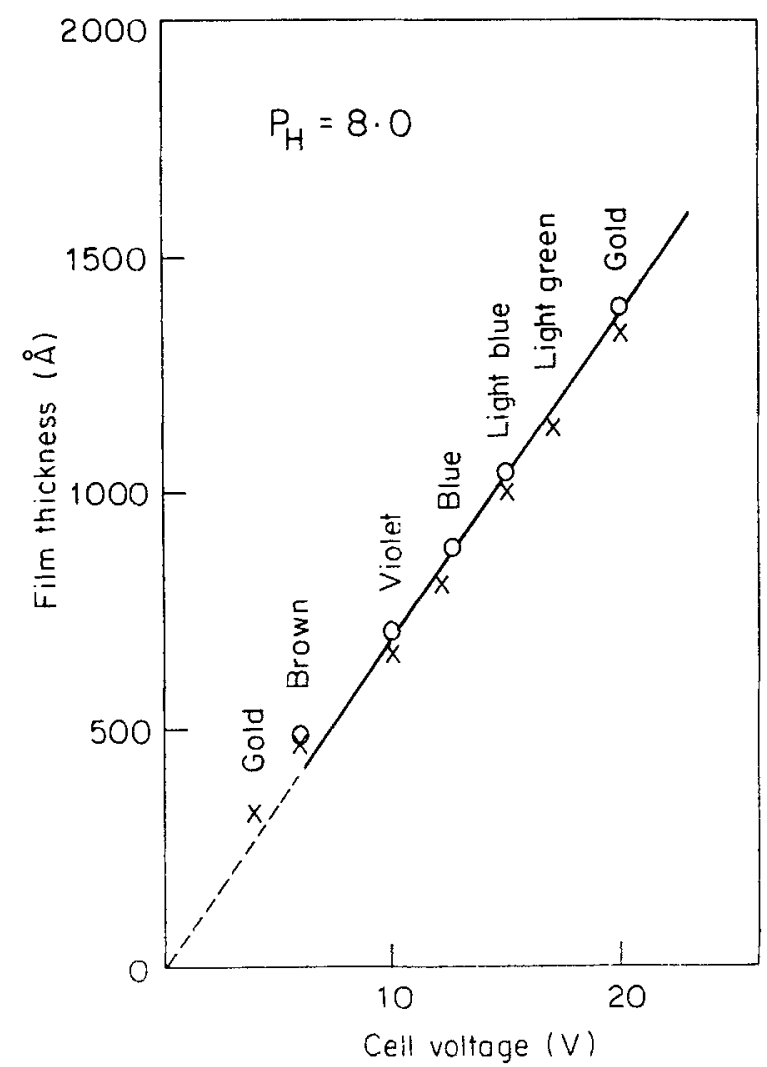

Figure 3. Oxide film thickness and its colour vs cell voltage at a current density $1 \mathrm{~mA} / \mathrm{cm}^{2}$. 


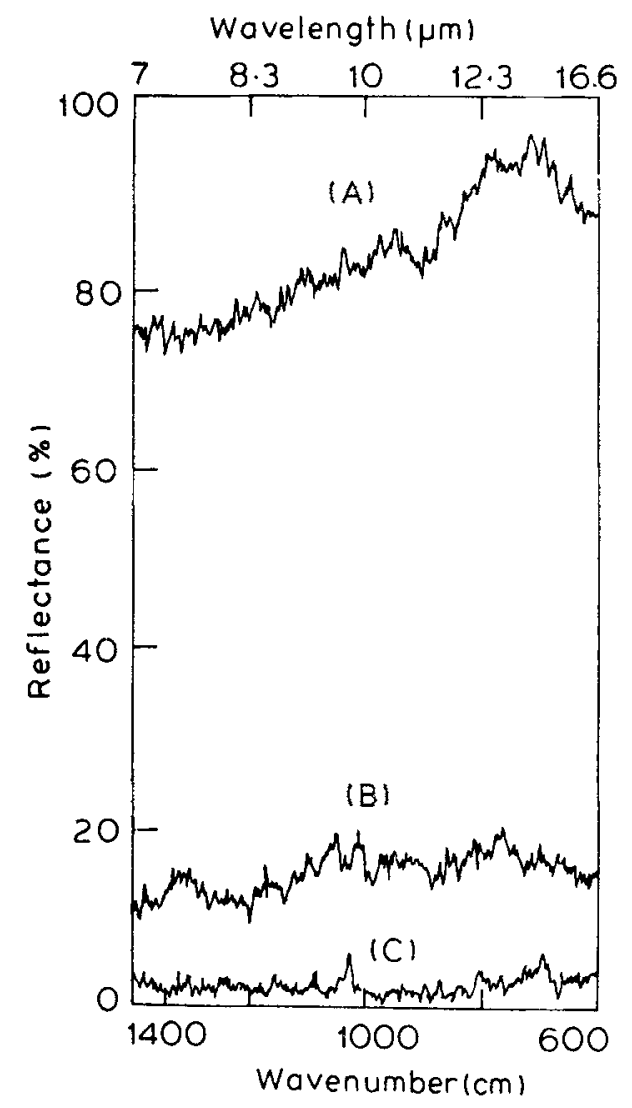

Figure 4. Reflectance vs wavelength for $\mathrm{Hg}_{08} \mathrm{Cd}_{0.2} \mathrm{Te}$ with and without oxide. Curve $(\mathbf{A})$ is the reference signal and curves $(\mathbf{C})$ and $(\mathbf{B})$ are with and without oxide films.

and $t_{1}$ and $t_{2}$, the respective thicknesses. In the calculation of the refractive index of $\mathrm{SiO}_{2},\left(n_{1}\right)$ is taken to be 1.48 and the refractive index of oxide grown is taken as 2.18 assuming that the main component of the anodic oxide is $\mathrm{TeO}_{2}$. As shown, there is a fairly good agreement between the experimental and the theoretical value of different cell voltages. The refractive index of $\mathrm{TeO}_{2}$ is nearly equal to that of $\mathrm{ZnS}$ (Debenham $1984)$ and $\mathrm{ZnS}$ is used as an anti-reflection coating in the range $7-16.6 \mu \mathrm{m}$. This leads us to measure the reflectivity of the oxide film and compare with that of unoxidized samples of MCT. The anodic oxide film shows an anti-reflection effect. The results are shown in figure 4 which substantiate our assumption that the main component of the anodic film of $\mathrm{MCT}$ is $\mathrm{TeO}_{2}$. The growth of $1000 \mathrm{~A}$ thick $\mathrm{TeO}$, consumes about $1500 \mathrm{~A}$ of MCT.

The anodic oxides are not chemically attacked by organic solvents such as acetone, benzene, trichloroethylene. glycol, methanol, ethanol and carbon tetrachloride. The transparent film is easy to etch. The solubility properties of the oxide in acid and alkaline solutions and the surface obtained after etching are given in table 1 . It is clear from the table that $\mathrm{HCl}$ or $\mathrm{NH}_{4} \mathrm{OH}$ easily dissolves the oxide and gives a smooth polished surface. $\mathrm{HCl}$ or $\mathrm{NH}_{4} \mathrm{OH}$ can therefore be used to delineate the oxide film to any shape using standard photolithography. 
rable 1. Solubility of the anodic oxide film in acid and alkaline solutions and surface of the crystal after etching.

\begin{tabular}{lll}
\hline Solution & Solubility & Etched surface \\
\hline $\mathrm{HCl}$ & Fasily dissolves & Smooth polished surface \\
$\mathrm{HNO}_{3}$ & Fast action & A layer remains \\
$\mathrm{H}_{2} \mathrm{SO}_{4}$ & Slowly dissolves & Not smooth \\
$\mathrm{HF}$ & Slowly dissolves & A layer remains \\
$\mathrm{HBr}_{2}$ & Slowly dissolves & Rough \\
$\mathrm{NH}_{4} \mathrm{OH}$ & Easily dissolves & Smooth polished surface \\
$\mathrm{NaOH}_{\mathrm{KOH}}$ & Slowly dissolves & Not smooth \\
& Dissolves very very slowly & A layer remains \\
\hline
\end{tabular}

\section{Conclusion}

The condition of forming a good anodically oxidized film on $\mathrm{Hg}_{0.8} \mathrm{Cd}_{0.2} \mathrm{Te}$ is studied. The electrolyte composed of $0.1 \mathrm{~N} \mathrm{KOH}, 90 \%$ ethylene glycol. $10^{\prime \prime}{ }_{0} \mathrm{H}_{2} \mathrm{O}$ when adjusted to $\mathrm{pH}=7$ to 8 gives good transparent film for cell voltages upto $25 \mathrm{~V}$. $\mathrm{HCl}$ and $\mathrm{NH}_{4} \mathrm{OH}$ can be used as a useful etchant to delineate the oxide film to any shape.

\section{Acknowledgement}

The results reported in this paper were presented at the National Symposium on Thin Film Science and Technology, Bangalore, January 1985.

\section{References}

Catagnus P C and Baker C T L S 1979 Pat. 3977,01X

Debenham M 1984 Appl. Op. 232238

Dornhaus R and Nimtz (; 1983 in Springer traces in modern physus wed.) R Hohler (Borlin: Spronger Verlag) vol. 98 p. 119

Ghandhi S K 1983 ITSI fabricutun prinopless, silicon and gallium arse'nide (New York: John Wiley) p. 371

Gupta S C and Richter H J 1983 J. Eletwochem. Sox. 1301469

Willardson R k and Beer A C 1981 Senmondasms and semimesal. (New Vork: Academic Press) wol ts 